\title{
Estimation of flood environmental effects using flood zone mapping techniques in Halilrood Kerman, Iran
}

\author{
Siamak Boudaghpour ${ }^{1}$, Majid Bagheri ${ }^{1 *}$ and Zahra Bagheri ${ }^{2}$
}

\begin{abstract}
High flood occurrences with large environmental damages have a growing trend in Iran. Dynamic movements of water during a flood cause different environmental damages in geographical areas with different characteristics such as topographic conditions. In general, environmental effects and damages caused by a flood in an area can be investigated from different points of view. The current essay is aiming at detecting environmental effects of flood occurrences in Halilrood catchment area of Kerman province in Iran using flood zone mapping techniques. The intended flood zone map was introduced in four steps. Steps 1 to 3 pave the way to calculate and estimate flood zone map in the understudy area while step 4 determines the estimation of environmental effects of flood occurrence. Based on our studies, wide range of accuracy for estimating the environmental effects of flood occurrence was introduced by using of flood zone mapping techniques. Moreover, it was identified that the existence of Jiroft dam in the study area can decrease flood zone from 260 hectares to 225 hectares and also it can decrease $20 \%$ of flood peak intensity. As a result, $14 \%$ of flood zone in the study area can be saved environmentally.
\end{abstract}

Keywords: Catchment area, Environmental damages, HEC-HMS, HEC-RAS, GIS, Jiroft dam

\section{Introduction}

The reports of floods in different parts of the world reveal the same scenario of enormous environmental and economic damages and human death for decades [1,2]. At riversides, floodplain areas are more subjected to possible flood events. From one hand, extensive volume of runoff increases the magnitude of overflow. From another hand, previous studies have shown that sedimentation due to flood occurrence decreases the main river bed [3,4]. In many ephemeral streams, high concentrations of suspended sediments are commonly observed [5-7]. They can be as much as 200,000 ppm weighing ( $9 \%$ by volume) leading to hyper concentrated flows conditions (generally from 1 to $25 \%$ ) [8].

Because of geological characteristics in Iran, there is a high probability of flood and it also has the capacity to transmit mud and sediments. For the sake of this reason,

\footnotetext{
* Correspondence: bagherimajead@yahoo.com

${ }^{1}$ Department of Civil Engineering, K.N. Toosi University of Technology, Vanak Square, Tehran, Iran

Full list of author information is available at the end of the article
}

floods often make extensive damages in Iran. Flood occurrence, much the same one happened in Halilrood catchment area in 1992 brings about remarkable environmental effects such as sediment transmission in addition to financial and severe damages. To examine the effects of damages caused by flood in the regions adjacent to river consisting of agricultural lands, woods and structures, models were performed, which finally introduce flood zone in the area. It is possible to classify environmental effects of floods at the regions adjacent to the river with the aid of flood zone map. By considering flood dangers, development of regions adjacent to the river can be anticipated. Flood map, often referred to as "flood risk" or "hazard map", presented in a graphical format of the areas of land or property that have been flooded long ago or are considered to be at risk of flooding $[9,10]$. The maps can display a range of parameters and different types of information, such as flows, water levels, depths, etc.

Hydrologic engineering center-hydrologic modeling system (HEC-HMS) model was developed by the U.S. 
army corps of engineers that could be applied in many hydrological simulations [11]. The HEC-HMS model can be applied to analyze urban flooding, flood warning system planning, flood frequency, stream restoration, reservoir spillway capacity, etc. [12]. The HEC-HMS contains four main components including: (1) An analytical model to calculate overland flow runoff as well as channel routing, (2) an advanced graphical user interface illustrating hydrologic system components with interactive features, (3) a system for storing and managing data, specifically large, time variable data sets, and (4) a means for displaying and reporting model outputs $[12,13]$. Hydrologic engineering center-river analysis system (HEC-RAS), which was developed by the U.S. army corps of engineers, has been applied extensively in calculating the hydraulic characteristics of rivers [11]. HECRAS calculates one-dimensional steady and unsteady flows, and the model equations are also described by Harriett and Bates [14]. To execute the model, details of cross sections of the river and upstream flow rate are required. Using the energy conservation equation, the velocity and water depth of the given cross section are figured out [15]. The development of the present flood model integrates geographic information system (GIS) with the HEC-HMS rainfall-runoff model and the HECRAS river hydraulic model [16].

Numerous past studies have shown that these models direct accurate and useful results in flood related studies [17-19]. Liu and Zhao established a hydrological information system using GIS, hydrological modeling system and hydrological parameters of the catchment area such as hydraulic group of soil, concentration time and runoff coefficient [20]. The hydrological information system was utilized to manage of runoff and rainfall models at the area. They specified that accuracy of hydrological models based on data from GIS, is remarkable and practical in flood management so that reliable results can be obtained [20,21]. Knebl et al. have developed a framework for regional scale flood modeling that integrates radar-based rainfall estimation using next generation radar (NEXRAD) Level III rainfall, GIS, and a hydrological model (HEC-HMS/RAS) [16]. The model consisted of a rainfall-runoff model (HEC-HMS) that converted precipitation excess to overland flow and channel runoff, as well as a hydraulic model (HEC-RAS) that models unsteady state flow through the river channel network based on the HEC-HMS-derived hydrographs. The modeling framework presented in this study incorporated a portion of the recently developed GIS tool named map to map. The results indicated that this research will benefit future modeling efforts by providing a tool for hydrological forecasts of flooding on a regional scale. While designed for the San Antonio River Basin, this regional scale model can be used as a prototype for model applications in other areas of the country [16].

The current research was an effort to develop flood zone maps to accurately estimate the flood environmental effects in Halilrood catchment area of Kerman province, Iran. The flood zone map for the considered area was developed in four steps. The first to third steps were bases to calculate and estimate the flood zone map in the intended area. The environmental effects of flood occurrence for the considered area were estimated based on the output (flood zone) of the forth step. The study at Halilrood catchment area aimed to determine flood zone, witch the zone obtained with the aid of Arc GIS 9.3, HEC-HMS 3.3, HEC-RAS 3.1.3, ArcView 9.x software, HEC-GeoHMS 4.2.92 and HEC-GeoRAS 4.1.1 software. To the best of our knowledge, this is the first effort utilizing flood zone maps to accurately estimate flood environmental effects.

\section{Materials and methods}

To identify an area's flood risk, flood insurance studies are developed [22]. These studies include statistical data for river flow, storm tides, hydrologic/hydraulic analyses, and rainfall and topographic surveys. This data is practiced to create the flood hazard maps or flood zone maps that outline an area's different flood risks. These digital flood zone maps provide an official depiction of flood hazards for each area and for properties located within it. These zone maps cannot be used for flood insurance purposes, but they will show the boundaries of flooded areas for the $1 \%$ of annual chance (100-year) and $0.2 \%$ of annual chance (500-year) floods. There is a possibility of river floods in large catchment areas due to long duration rainfalls. The river floods predominantly taking place at mountainous regions and have discharged with high peak and low based time. A characteristic of a river flood in large catchment in semi-arid areas is its intense dissipation along the main river. Sometimes by extending rainfall over the area, large flood occurrences can be imagined, which cause irreparable financial and serious damages, especially at floodplain areas. The main purpose of this research is to evaluate environmental damages caused by floods using flood zone maps. We carry out the evaluation of governing conditions in flood occurrence and its flood zone in a large catchment located at semiarid area. Natural and artificial dams upset stream flow regime by trapping sediment and impeding the flow of water. According to the extensive literature on the geomorphic effects of reservoirs, following adjustments can be expected following river impoundment: decreases in peak flows, bed load discharge, width and bank full crosssectional area, floodplain zone; increases or decreases in depth, gradient and sinuosity [23]. According to the fact that dam affects flood zone map, effect of storage reservoir 
on the river discharge during flood event and flood zone map has been regarded in this research. The impacts of changes in catchment area and rainfall pattern have also come into consideration. Studying Halilrood catchment area aiming to determine flood zone has been performed with the aid of Arc GIS 9.3, HEC-HMS 3.3, HEC-RAS 3.1.3, ArcView 9.x software, HEC-GeoHMS 4.2.92 and HEC-GeoRAS 4.1.1 software. These studies have been directed to recognize damages at different regions when possible floods occur and we can take necessary actions to decrease the environmental damages of flood occurrences at the area.

\section{Case study area}

Halilrood catchment area is situated in Kerman province at south east of Iran (Figure 1). It is located in Hamoon Jazmoriyan catchment area and it is between Barez Mountains at north and Makran Mountains at south. According to official statistics, Kerman province's population of 2961307 have been announced, totally 58\% of the population are living in urban areas and $42 \%$ are living in rural areas. There is also a good fertile soil and abundant groundwater, especially around the Jazmoriyan, which has provided suitable conditions to cultivate crops. Crops such as banana palm, mango, citrus and other crops such as barley, wheat and corn are native to these parts. Within past few years, there have been dense forests of Prosopis and Gaz at various regions, especially Rudbar, and Faryab. However, nowadays only about 80,000 hectares of forest land has remained of which 65,000 hectares as ruined forest, 10000 hectares of semi-dense forest and only 5,000 hectares of dense forest. Kerman province has several mines, most important of which are decorative stones, Lime, Marble, Gypsum. Other important mines are Coal, Iron, Chromites, Asbestos, Manganese, Turquoise and Titan. The highest elevation of the study area is equal to $4300 \mathrm{~m}$ at northern boundary and near the source of Halilrood. The lowest elevation in the outlet of study area is equal to $500 \mathrm{~m}$. Average elevation of the study area is equal to $1971 \mathrm{~m}$. About $70 \%$ of the area is composed of mountainous region and the rest of it is plain. Jiroft dam is on the Halilrood river at distance of $250 \mathrm{~km}$ from south of Kerman city and at $40 \mathrm{~km}$ of northeast of Jiroft city.

Selected physiographical characteristics of the area are shown in Table 1. Jiroft dam is effective in the flood

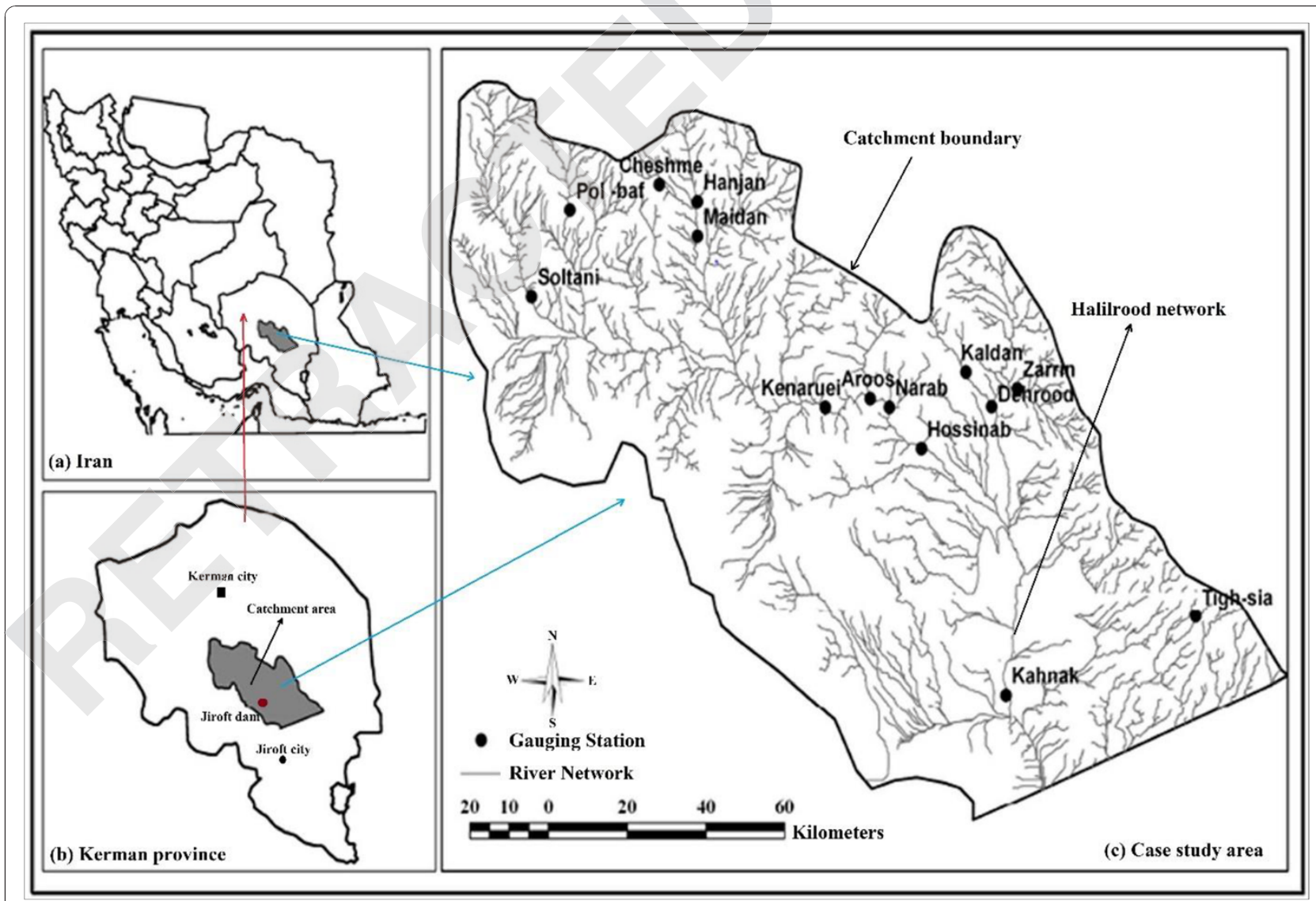

Figure 1 Location of the study area (a) location of the catchment area and Kerman province in Iran, (b) location of catchment area in Kerman province, (c) location of gauging stations in the catchment area. 


\begin{tabular}{ll}
$\begin{array}{l}\text { Table } 1 \text { Selected physiographical characteristics of the } \\
\text { study area }\end{array}$ \\
\hline Characteristic (unit) & Value \\
\hline Area $\left(\mathrm{km}^{2}\right)$ & 12990 \\
Perimeter $(\mathrm{km})$ & 1007 \\
Average slope & 0.1656 \\
Length of equivalent rectangular $(\mathrm{km})$ & 358.3 \\
Width of equivalent rectangular $(\mathrm{km})$ & 42.8 \\
Length of main waterway $(\mathrm{km})$ & 194 \\
Average elevation $(\mathrm{m})$ & 1971 \\
Maximum elevation $(\mathrm{m})$ & 4300 \\
Minimum elevation $(\mathrm{m})$ & 500 \\
Concentration time $(\mathrm{h})$ & 34.6
\end{tabular}

zone mapping of the Halilrood catchment area. The relation between dam reservoir, which affects flood environmental damages and elevation is illustrated in Figure 2. There is a gauging station at the end of the area (Kahank), which the catchment area was evaluated about $13000 \mathrm{~km}^{2}$ at this station. Halilrood at northwest of its catchment flows over a bed, which covered with coarse sediments due to the high elevation of the catchment at its branches. Inside the plain by decreasing the slope of the river, bed bottom is covered gradually with fine sediments and in the coastal areas it is covered with silt and marl. In the upper parts of the river route, water penetrates into the soil and enriches underground water sources.

\section{Model development}

By development of new technologies, available methods to prepare flood zone maps require using of more efficient tools. From one point, new and developed mathematical models give extensive facilities to more precise analysis of flood, and in another aspect, they have many abilities to make flood zone maps and display them with the aid of GIS [24]. By using GIS and a hydrological model, it is possible to apply probable scenarios, perform and update maps simply with spending much less time and money. Such a system gives remarkable abilities to practitioners for management of floodplain areas before flood occurrence, disaster management when flood occurs, reconstruction after flood occurrence.

With the development of numerical modeling, GIS, and digital elevation models (DEMs), automated techniques and methods become available and have been widely used in floodplain delineation. DEMs have been widely used in automated floodplain modeling to determine floodplain boundaries [25]. These automated methods significantly reduce the time and improve the accuracy of the floodplain delineation. The source and resolution of the DEM would affect many steps of the floodplain modeling.
With technological advances, DEMs can be created at much higher resolutions $[22,25]$. The effects of DEM resolution and data source have been examined for watersheds, and hydrological models are tested if an optimum DEM resolution exists, so the model output can be accurate enough without the need to significantly increase data storage space and computation ability [26]. Table 2 lists a number of DEMs, which have been used in earlier studies along with internet addresses where data can be accessed. DEMs considered in the current research include airborne interferometric synthetic aperture radar (IfSAR) data at $3 \mathrm{~s}$ resolution $(90 \mathrm{~m}$ ) based DEMs available from NOAA/CSC or commercially (from Intermap Corp.).

To determine flood zone maps, DEM, which includes IfSAR and Arc GIS 9.3 software were utilized for required analysis at modeling processes of the Halilrood catchment area. Then by using relations between rainfall and runoff, flood has been simulated. The model at the outlet of catchment area has been calibrated at this simulation process by using of hydrological modeling system (HEC-HMS 3.3), which is used in flood inundation mapping and using observed data [12,28]. Then flood hydrographs with different periods have been routed for different reservoir conditions and at last flood zone mapping for a part of Halilrood catchment area has been developed. We practiced four steps to achieve all goals at the research. These steps are: (1) generation of data base, (2) hydrological modeling, (3) hydraulic modeling, and (4) flood zone mapping. The four steps are bases to determine environmental effects of floods on the area. Furthermore, by considering the forth step, which flood zone map is its outlet, we determine the probable environmental effects and other damages at the area, so that we have a sense about flood dangers at the study area. With regarding to the main goals of our research, overall process of this study has been shown in Figure 3.

In this research, soil conservation service (SCS) method has been used, which is an effective rainfall estimation method to correlate the relation between runoff and rainfall. The SCS curve number $(\mathrm{CN})$ method implements the curve number methodology for incremental losses. Originally, the methodology was intended to calculate total infiltration during a storm. The program computes incremental precipitation during a storm by recalculating the infiltration volume at the end of each time interval. In filtration during each time interval is the difference in volume at the end of two adjacent time intervals [12]. The SCS CN method requires percentage land use pattern of the catchment and the sub catchments, total length of the river and the elevation of the catchment area. SCS CN model estimates precipitation excess as a function of cumulative precipitation, soil cover, land use and antecedent moisture content [11]. The maximum retention and 


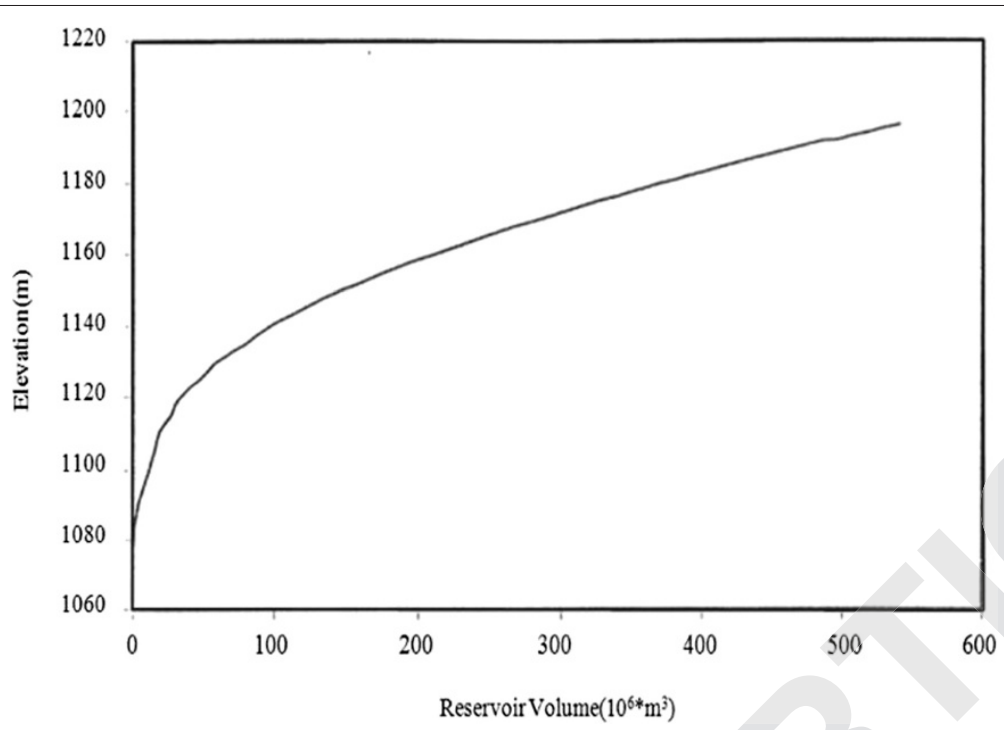

Figure 2 Relation between Jiroft dam elevation and reservoir volume.

watershed characteristics are related through an intermediate parameter, the curve number. The $\mathrm{CN}$ values range from 100 (for water bodies) to approximately 30 for permeable soils with high infiltration rates [12]. This model relates the runoff to rainfall in according to a following equation.

$$
\begin{aligned}
& \frac{\mathrm{p}-\mathrm{I}_{\alpha}-\mathrm{Q}_{\mathrm{d}}}{\mathrm{S}}=\frac{\mathrm{Q}_{\mathrm{d}}}{\mathrm{p}-\mathrm{I}_{\alpha}} \\
& \mathrm{S}=\frac{25400}{\mathrm{CN}}-254
\end{aligned}
$$

Where $\mathrm{P}$ is amount of precipitation and expressed in $\mathrm{cm}, \mathrm{I}_{\alpha}$ is the primary losses and in $\mathrm{cm}, \mathrm{Q}_{\mathrm{d}}$ is runoff height over the area in $\mathrm{cm}$, and $\mathrm{S}$ is maximum storage capacity of whole catchment including all types of retention in $\mathrm{cm}$. In the equation (2) to determine $\mathrm{CN}$, it is essential to estimate hydrological conditions of the catchment area.
To determine unit hydrograph of the catchment area by using of SCS model, $T_{B}$ time of reaching to peak runoff and the maximum discharge value $\mathrm{Q}_{\mathrm{B}}$, should be calculated. After this coordinates of flow hydrograph, by using of coefficient of $T_{P}$ and $Q_{P}$ should be computed in a dimensionless ratio. Maximum discharge of unit hydrograph is derived by following equations.

$$
\begin{aligned}
& \mathrm{Q}_{\mathrm{p}}=\frac{2.083 \mathrm{AQ}_{\mathrm{d}}}{\mathrm{T}_{\mathrm{p}}} \\
& \mathrm{T}_{\mathrm{p}}=\frac{\mathrm{D}}{2}+\mathrm{T}_{\mathrm{L}} \\
& \mathrm{D}=0.2208 \mathrm{~T}_{\mathrm{L}}
\end{aligned}
$$

Where $Q_{P}$ is maximum discharge in $\mathrm{m}^{3} / \mathrm{s}, \mathrm{T}_{\mathrm{P}}$ is time

\begin{tabular}{|c|c|c|c|c|}
\hline Dataset & Link & Coverage & H.R. (m) & V.A. RMSE (m) \\
\hline $\mathrm{NED}-1 / 3 \mathrm{~s}$ & http://seamless.usgs.gov & USA and $\mathrm{HI}$ & $\sim 10$ & \pm 7 \\
\hline NED-1 s & http://seamless.usgs.gov & USA and $\mathrm{HI}, \mathrm{PR}, \mathrm{VI}$ & $\sim 30$ & $\pm 7-0.15$ \\
\hline NED-2 s & http://seamless.usgs.gov & Alaska & $\sim 60$ & $\pm 7-0.15$ \\
\hline SRTM-1 S & http://seamless.usgs.gov & USA and territories & $\sim 30$ & \pm 10 \\
\hline SRTM-3 S & http://seamless.usgs.gov & Global: $56 \mathrm{~S}-60 \mathrm{~N}$ & $\sim 90$ & \pm 10 \\
\hline Louisiana LiDAR & http://atlas.lsu.edu & LA & $\sim 3$ & $\pm 0.20-0.25$ \\
\hline North Carolina LiDAR & http://www.floodrisk.org.uk & NC & $\sim 3$ & $\pm 0.20-0.25$ \\
\hline NOAA CSC IfSAR & http://www.csc.noaa.gov & USA: CA & 3 & \pm 2.5 \\
\hline NOAA CSC LIDAR & http://www.csc.noaa.gov & Coastal USA & Variable & \pm 0.15 \\
\hline Intermap Corp. & http://www.intermap.com & International & Variable & Variable \\
\hline
\end{tabular}
of reaching to peak runoff in $\mathrm{h}, \mathrm{A}$ is catchment area in $\mathrm{km}, \mathrm{Q}_{\mathrm{d}}$ is runoff height over the area in $\mathrm{cm}, \mathrm{D}$ is duration of the flow in $h$, and $T_{L}$ is time lag in $h$.

Table 2 On-line accessible topographic datasets potentially useful for flood inundation modeling [27] 


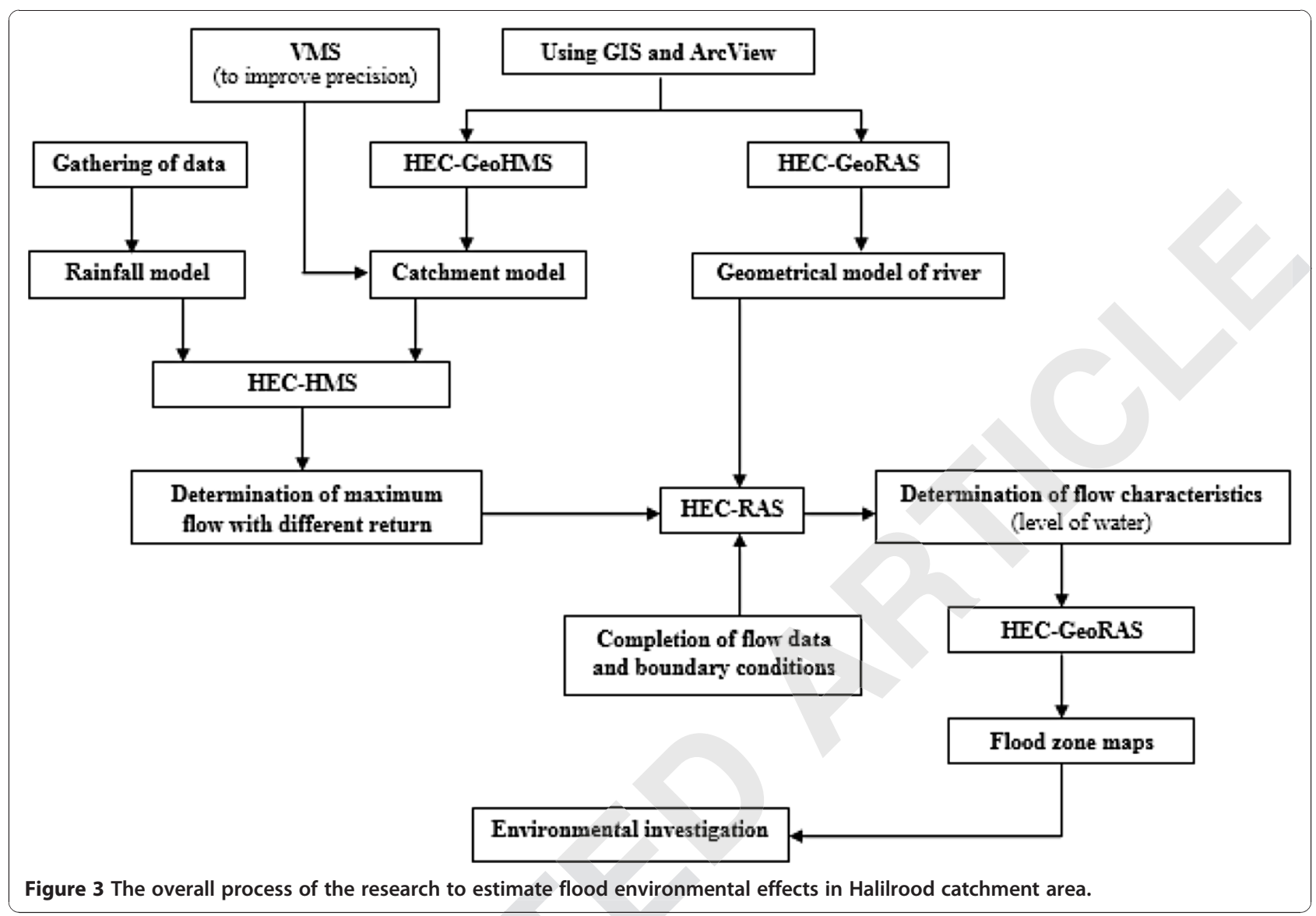

\section{Generation of data base}

Accurate data base is the basis of an accurate flood zonation. The generation of data base consists of two parts in this study. At the first part statistics and the data are gathered and at the next part data are processed. The hydrological studies have been proceed and DEM, which includes IfSAR data at $3 \mathrm{~s}$ resolution $(90 \mathrm{~m})$ has been used to perform flood zonation in the Halilrood catchment area. Plans containing contour lines from a part of Halilrood catchment area have been provided to do flood zonation studies. Rainfall statistics occurred in a selected day and its hourly measurements related to the flood at the gauging stations have been shown in Table 3. At this stage some data were gathered from local or state organizations. Daily average flow (average flow of each day) during a year is one of them that was gathered from gauging stations. To have a sense about average flow in the Halilrood catchment area daily average flow of the Kahank station during a year has been shown in Figure 4. The Kahank station, which is at the end of catchment area had a daily average flow about $70 \mathrm{~m}^{3} / \mathrm{s}$ when flood occurred at 1992 . Moreover, the daily average flow of Hossinab and Dehrood stations were 180 and $30 \mathrm{~m}^{3} / \mathrm{s}$, respectively when the flood occurred in 1992.

\section{Hydrological modeling}

The hydrological modeling was performed by DEM, which includes IfSAR data at 3 s resolution (90m) and HEC-GeoHMS 4.2.92 software. In order to determine subwatersheds and outlet situation of subwatersheds, gauging stations have been considered and by observed hydrograph calibration has been performed for subwatersheds [12,28]. In more detail explanation, at first, the study area is delineated in ArcView 9.x software. After this, required information is completed or corrected and watershed polygon processing is performed for the area, then by performing watershed aggregation, subwatersheds are separated. Indeed, subwatersheds, which can form a watershed are merged, then outlet point of the study area is specified and other part of the area is deleted (Figure 5). Due to the extent of the catchment area and in order to increase the accuracy and educing of the physiographical characteristics of the catchment area, watershed modeling system (WMS) has been used (Figure 5). After this stage input file to hydrological model (HEC-HMS 3.3), which contains physical scheme and physiographical characteristics of catchment area is made up. Then hydrological model is calibrated so that observed flood hydrograph and computational flood hydrograph should be the same. Generally calibration 
Table 3 Rainfall depth according to gauging stations in Halilrood catchment area

\begin{tabular}{llll}
\hline Station name & $\begin{array}{l}\text { Rainfall depth } \\
(\mathbf{m m})\end{array}$ & $\begin{array}{l}\text { Station } \\
\text { name }\end{array}$ & $\begin{array}{l}\text { Rainfall depth } \\
(\mathbf{m m})\end{array}$ \\
\hline Soltani & 28 & Narab & 70 \\
Pol-baf & 35 & Kaldan & 57 \\
Cheshme & 43 & Zarain & 48 \\
Hanjab & 47 & Dehrood & 39 \\
Maidan & 63 & Hossinab & 33 \\
Kenaruei & 51 & Tigh-sia & 45 \\
Aroos & 115 & Kahank & 45 \\
\hline
\end{tabular}

parameters depend on the type of method used. In this study due to using of SCS method at subwatersheds, two parameters including $C N$ and $T_{L}$ have been used. Table 4 represents $\mathrm{CN}$ and lag time of the subwatersheds after model calibration using SCS.

In this stage, flood hydrograph for dam and catchment area are important factors. Hydrograph of the inlet flood to Jiroft dam in the hydrometry station (Kenaruei) with 100 years return period has been shown in Figure 6 . At this stage by using of calibrated parameters, rainfall depth at the gauging stations with different return period, time distribution of the rainfall and that, Jiroft dam is in any conditions, simulated model of rainfall and runoff with 100 year return period was performed (Figure 7).

\section{Hydraulic modeling}

Determination of water level of a flow or a specific flood is the main goal of this stage, which to achieve this goal, it is essential to simulate flood flow at the river $[29,30]$.
In order to perform hydraulic modeling, Arc GIS 9.3 software is used as researching tool and HEC-RAS 3.1.3 is used to simulate the flow. At first, river network plan is prepared and cross section data is gathered to simulate the flow. Then in all cross sections Manning roughness coefficient is estimated and input data to HEC-RAS 3.1.3 is created. The flow measurement and water level data at the first and latest stations (boundary conditions) are gathered in this stage. Regarding to governing conditions in the case study area, given boundary condition is in normal depth due to slope of the river bed at downstream. The roughness coefficient is equal to 0.015 for the case study area. In order to simulate the hydraulic behavior of flow by using of digital models, it is essential to calculate roughness accurately because it is a factor to dissipate energy. In the current research, roughness has been considered in the modeling (Table 5). The case study area locates at downstream of Jiroft dam and this part of the catchment has $5 \mathrm{~km}$ length. In hydraulic modeling using the HEC-GeoRAS 4.1.1, the lines along the river are defined in order to extract required cross sections to simulate one dimensional flow layer of cross section. After this by completing flow line layer and its features, river cross section is obtained with regard to defined topographic conditions for the river and floodplain.

\section{Processing of data and preparing of flood zone map}

By remarking simulated model of the river flow and verifying of the results, the results of flow zone and width of inundation are used in ArcView 9. $x$ in order to determine the flood zone map. This software, by considering of given data develop a topographic model from water level and then by comparison of water level topography

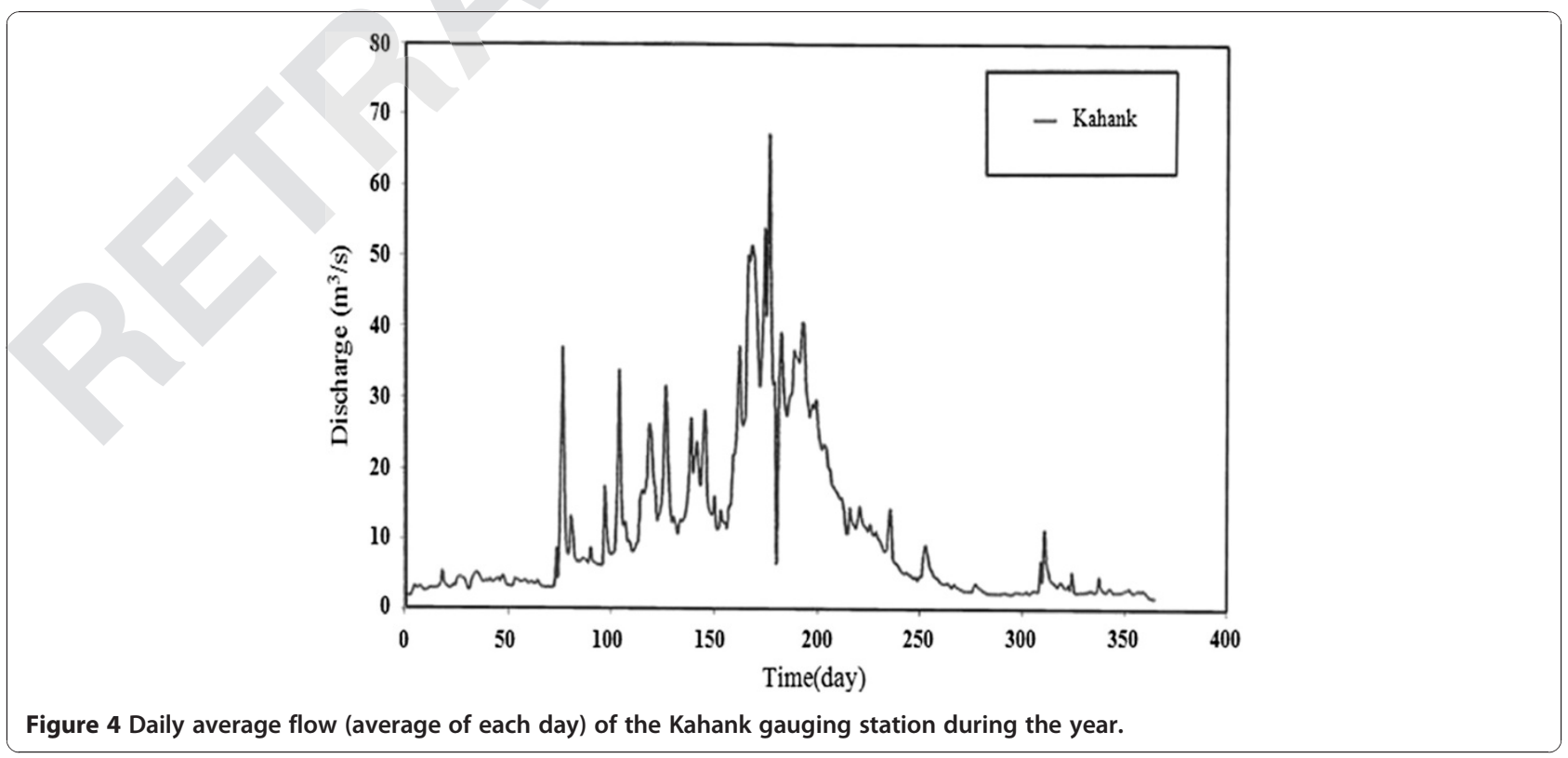



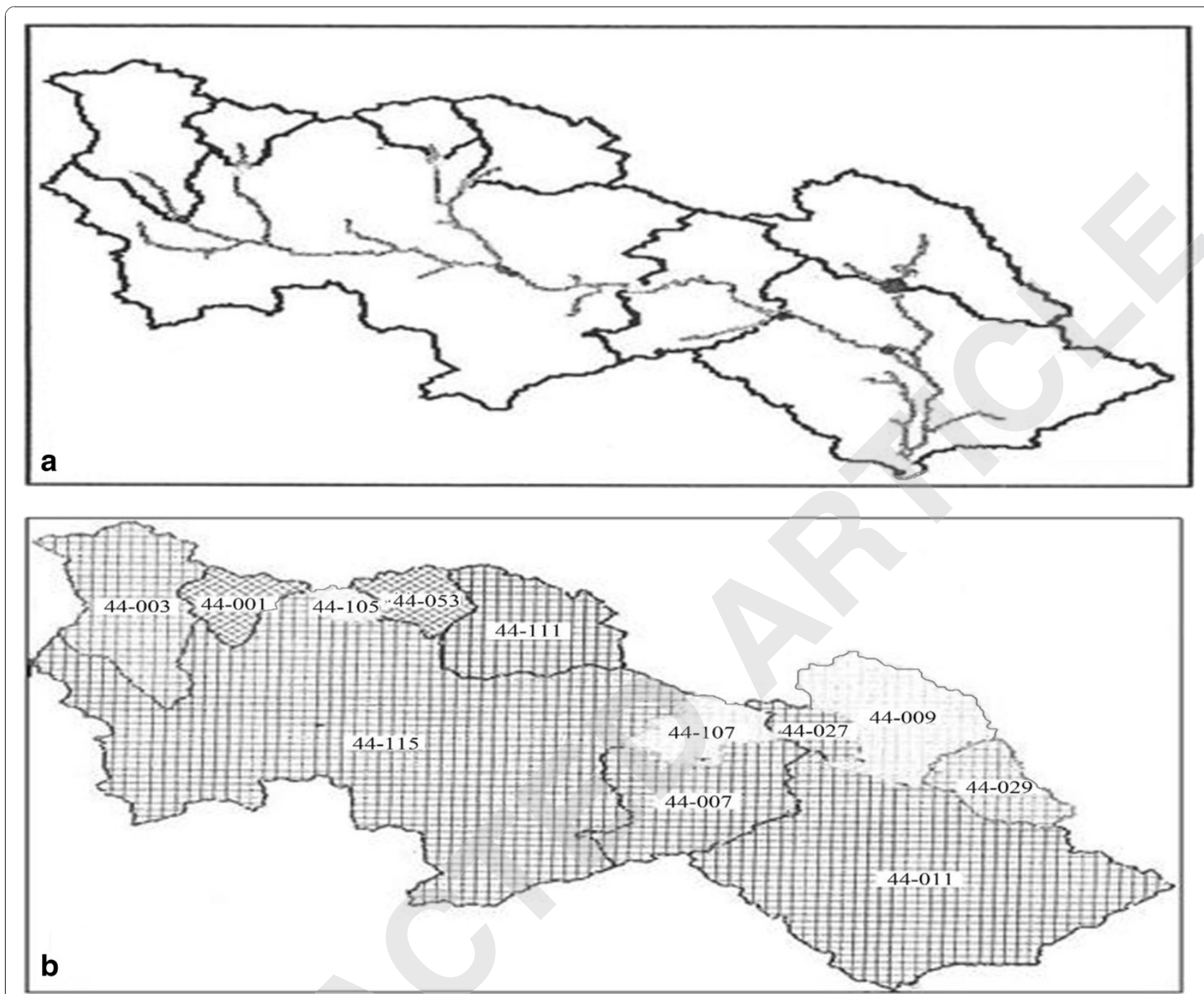

Figure 5 Selection of case study catchment at the area (a), Subwatersheds determination by using of WMS model and their names (b).

Table $4 \mathrm{CN}$ and lag time of the subwatersheds after model calibration

\begin{tabular}{lll}
\hline Sub watershed code & CN value & Lag time $(\mathbf{m i n})$ \\
\hline $44-001$ & 72 & 412 \\
$44-003$ & 73 & 690 \\
$44-007$ & 62 & 435 \\
$44-009$ & 72 & 464 \\
$44-011$ & 56 & 672 \\
$44-027$ & 65 & 225 \\
$44-029$ & 69 & 280 \\
$44-053$ & 73 & 244 \\
$44-105$ & 76 & 126 \\
$44-107$ & 71 & 195 \\
$44-111$ & 74 & 407 \\
$44-115$ & 72 & 935 \\
\hline
\end{tabular}

with ground topography flood zone map is prepared for the Halilrood catchment area.

\section{Analytical methods and data collection}

Formation of byproducts by corrosive waters, taste, odor and color problems in water as well as increase in turbidity are of the most important problems relate to corrosion. A simple method to determine water tendency to corrosion or sedimentation is the examination of Langelier saturation index (LSI) and Risener index (RI). In this method when the numerical value of LSI is positive, it means there is a tendency to carbonate sedimentation and corrosion whereas negative value is vice versa and we have $-1<\mathrm{LSI}<+1$. In addition, the $6.8<\mathrm{RI}<8.5$ indicates that the water is aggressive. The Langelier Saturation Index and Risener Index are calculated according to following equations, and the detailed descriptions of these equations are available in some references [31]. 


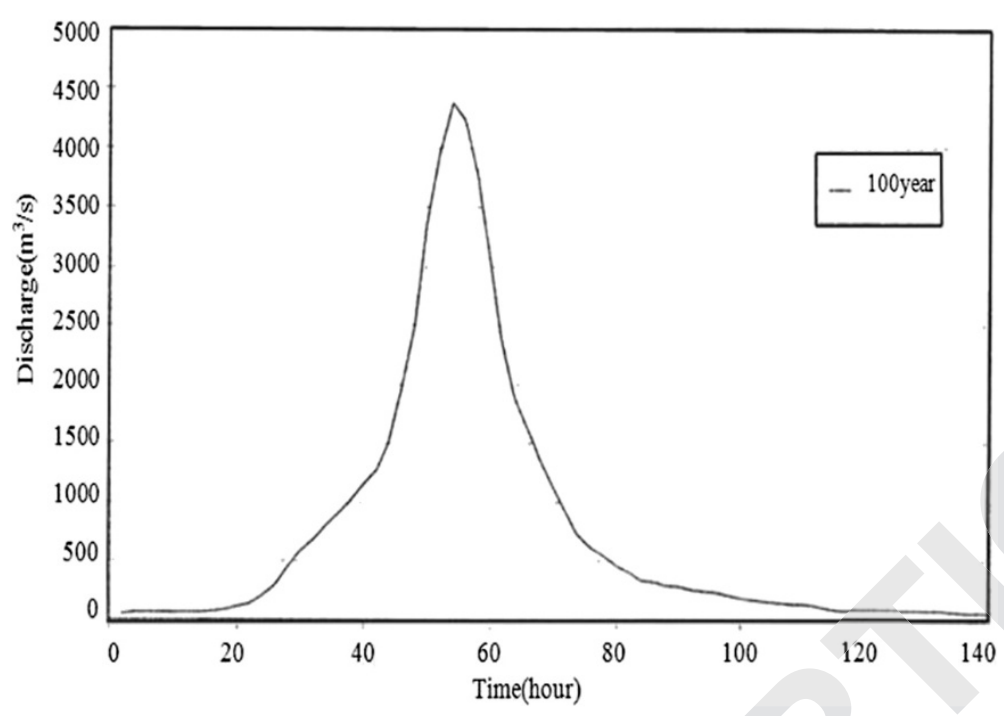

Figure 6 Inlet flood hydrograph of Jiroft dam by 100 years return period.

$$
\begin{aligned}
& \mathrm{LSI}=\mathrm{pH}-\mathrm{pH}_{\mathrm{s}} \\
& \mathrm{RI}=2 \mathrm{pH}_{\mathrm{s}}-\mathrm{pH}
\end{aligned}
$$

Where $\mathrm{pH}_{\mathrm{S}}$ is saturation $\mathrm{pH}$ and $\mathrm{pH}$ is equal to $\mathrm{pH}$ value.

Temperature, $\mathrm{pH}$, dissolved oxygen (DO), biochemical oxygen demand (BOD), chemical oxygen demand (COD), total suspended solids (TSS), total dissolved solids (TDS) concentrations as well as Copper $(\mathrm{Cu})$ and Iron $(\mathrm{Fe})$ were measured in this study. The $\mathrm{pH}$ and temperature were measured using a digital $\mathrm{pH}$ meter. A dissolved oxygen meter (YSI 5000) was utilized to determine DO. Biodegradability was measured by 5 -day $\mathrm{BOD}_{5}$ test according to the standard methods [32]. The seed for $\mathrm{BOD}_{5}$ test was obtained from the Halilrood catchment area [33]. COD was determined according to the standard methods [32]. In the wastewater treatment plant laboratory, $\mathrm{Cu}$ and $\mathrm{Fe}$ were measured using a spectrophotometer (the Hach DR 5000 UV-Vis Laboratory Spectrophotometer). The past recorded data related to flood occurrence in Halilrood catchment area in 1992 were obtained from Iran environmental protection agency and other local organizations in the Kerman province.

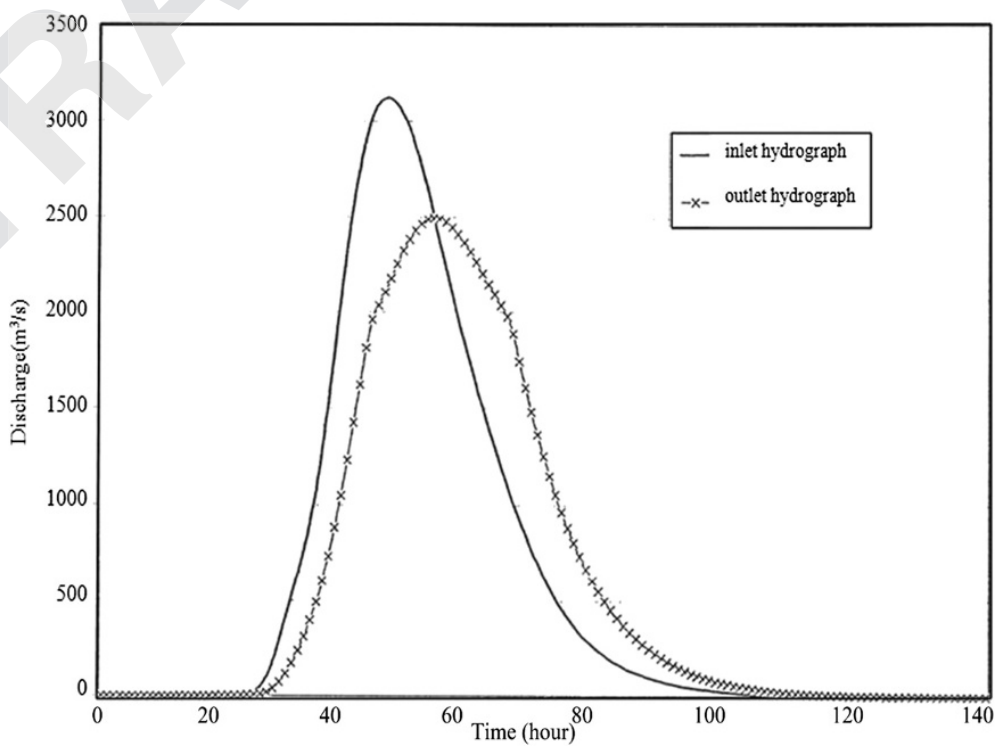

Figure 7 Flood hydrographs at the outlet of catchment area by 100 years return period. 
Table 5 Determination of Manning roughness coefficient for the study area

\begin{tabular}{|c|c|c|c|c|c|c|c|}
\hline \multirow{2}{*}{$\begin{array}{l}\text { Final } \\
\text { manning } \\
\text { coefficient }\end{array}$} & \multirow{2}{*}{$\begin{array}{l}\text { Degree of coefficient } \\
\text { of curvature of } \\
\text { river }(m)\end{array}$} & \multicolumn{5}{|l|}{ Coefficient } & \multirow[t]{2}{*}{ Situation } \\
\hline & & Vegetation & Barriers & Changes of section & $\begin{array}{l}\text { Unevenness degree at } \\
\text { the bed surface }\end{array}$ & Aggregation & \\
\hline 0.053 & 1 & 0.01 & 0.01 & 0.0001 & 0.005 & 0.028 & Bed \\
\hline 0.06 & & & & & & & Left bank \\
\hline 0.06 & & & & & & & Right bank \\
\hline
\end{tabular}

\section{Results and discussion}

\section{Modeling outcomes and Jiroft dam effects}

Flood zone map was prepared by considering of dam existence and without it. After processing of data flood zone map was completed and it is a base to investigate environmental effects and other damages of flood event. Some field investigations were carried out at the study area to increase the accuracy of the research. Figure 8 shows the flood zone map by 100 years return period, with and without Jiroft dam for the study area. Existence of dam resulted in decrease of flood zone area and so much less lands are endangered by floods so that environmental effects and damages of flood at the study area decrease clearly. At this point of view, Jiroft dam was engaged in the flood zone map and research. To study environmental effects and damages caused by flood occurrences in Halilrood catchment area it was observed the Jiroft dam located in the area has some environmental effects in addition to those of flood zone map. These effects become more serious and they will be more intense when flood occurs, therefore their considering and analyzing were performed by using flood zone map. The results of flood zone mapping indicated that the existence of Jiroft dam in considered area can decrease flood zone from 260 hectares to 225 hectares and also it decreases $20 \%$ of flood peak intensity therefore $14 \%$ of flood zone can be saved environmentally. According to the results of earlier studies swaying of water level because of flood event has some effects on biological life at shallow and coastal regions of the river negatively and also causes erosion of river banks and instability of slopes [34-36]. Based on the results of our field investigation, the rising of water level in reservoir at the time of flood event in 1992 changed the water characteristics and static condition of water. Sedimentation conditions, which impoverish downstream water flow was one of the most important changes when flood occurred in Halilrood catchment area. Settlement of heavy metals

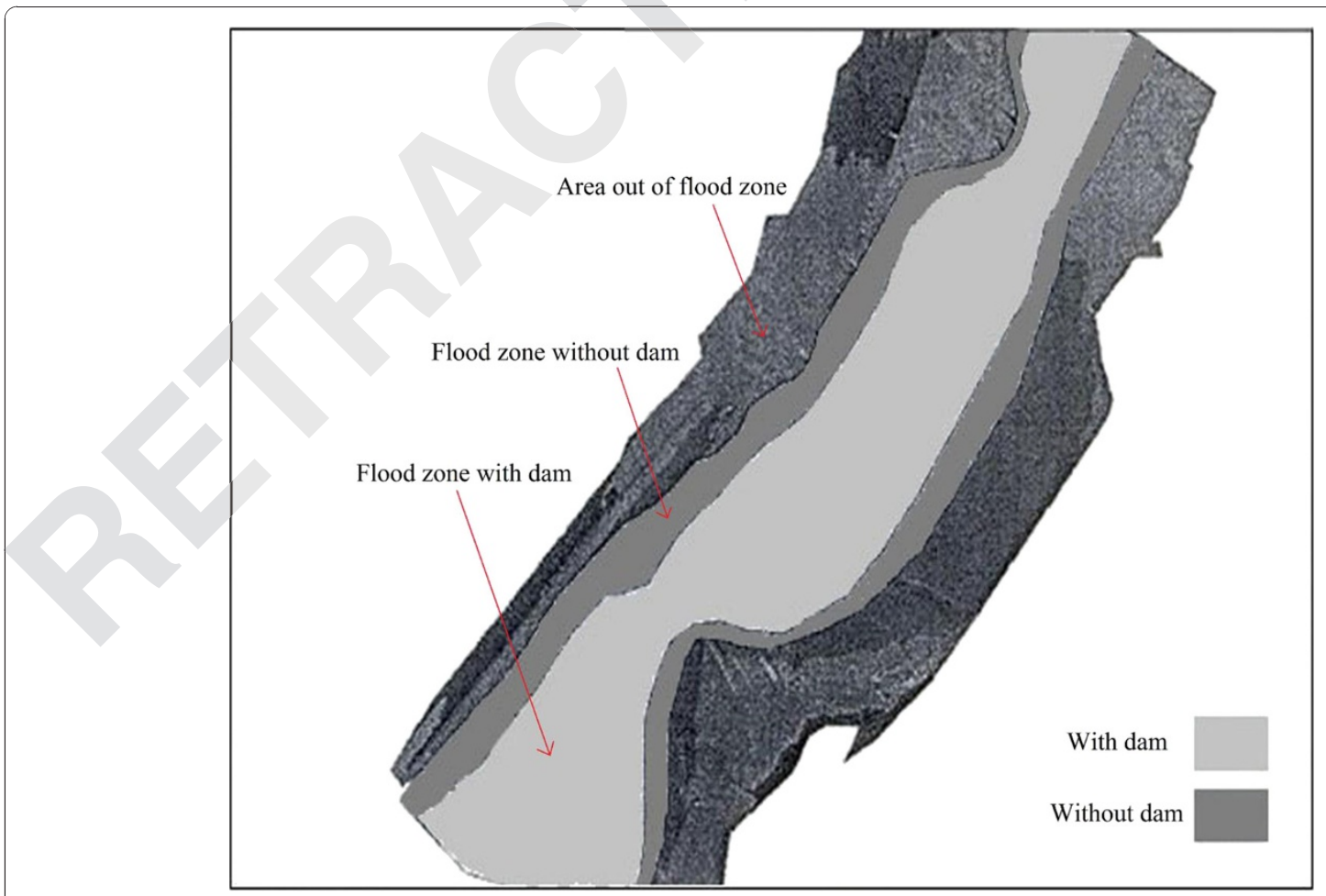

Figure 8 Flood zone map by 100 years return period, with and without Jiroft dam for the case study area. 
and accumulation of them after flood event in river and reservoir bed caused significant environmental damages in the study area. The analysis of past recorded data related to flood event in 1992 showed that the TSS concentration in the water increased to about $1500 \mathrm{mg} / \mathrm{L}$ while the environmental standard limit in Iran is $60 \mathrm{mg} /$ $\mathrm{L}$ for surface water. On the other hand, our analysis indicated that the TSS concentration did not exceed 300 $\mathrm{mg} / \mathrm{L}$ in the water for regions, which were not in the flood zone. As a results, the flood zone mapping can be introduced to determine the intensity of flood environmental effects in different regions.

\section{Flood environmental effects on groundwater}

Variations of nutrient, bacteria, and macrofauna dynamics in Halilrood river underlined the importance of flood events in ground water especially concerning numbers of active bacteria [37]. Studies on bacterial communities in sediment show positive correlations of bacteria numbers with organic matter content and oxygen values [38]. Although this phenomenon supporting groundwater and decreasing water hardness, which assumed as a positive effect, sediments in a long time period decrease the correlation between reservoir and ground water connection and at last slow down the supporting of ground water. In addition, after flood occurrence ground water level comes up and humidity of the soil increases then during sunny days evaporation of the water increases and causes salt appears at the upper layers of soil. Salty soil affects plants, destroys natural vegetables, decreases value of habitants and disrupts food chain at the area. Furthermore, another environmental effect observed after flood event in the catchment area is the necessity to more drainage of agricultural lands due to rising of ground water level. This issue increases the agricultural wastewater and results in pollution of water by fertilizers and other inorganic materials. It was observed that the agricultural land around river banks endanger by flood flow and according to our calculations of flood zone map more than 60 percent of land goes under water can produce agricultural wastewater, which is a noticeable environmentally.

\section{Flood effects on wildlife and aquatic}

Abundance of water during and after flood occurrence affects wildlife and ecology of the river. Based on the findings of the Iran environmental protection agency some of the animals and organisms cannot acclimatize themselves with new conditions after flood event in the Kerman province, therefore their life is impressed easily. Regarding to the flood zone map calculations in the study area approximately $17 \mathrm{~km}^{2}$ of land can be sunk during flood event. This matter affects the lives of some animals near the Halilrood catchment area and threatens their habitats therefore, their life is endangered by new conditions. The reduction of breeding is taken place because these animals lose their habitats. Furthermore, the diversity of environmental and geographical conditions of Kerman province can exacerbate the flood effects on wildlife of the Halilrood catchment area. The most endangered mammals are foxes, jackals, hyenas, wild cats and caracals. The Iran environmental protection agency found that the population of wolves, foxes, and jackals decreased by $30 \%, 25 \%$ and $35 \%$, respectively due to lose of habitants and severe environmental conditions after flood event in 1992 in Halilrood catchment area. The Iran environmental protection agency considered $5 \%$ of the Kerman province as protected areas in order to restore the habitats of these mammals after 1992.

\section{Flood environmental effects on plants}

Decreasing plants on the ground results in probable negative changes at the area. Adult trees tolerate flooding better than over mature trees or seedlings of the same species [39]. Therefore, some species rated as flood tolerant may be quite sensitive in the seedling stage. Seedlings often die because they are pushed over and buried in mud or uprooted. Another important matter is the effects of flood on trees and other plant notably on orchard and vegetables, which are food sources for local people at the area. When flood occurs heavy metals that have been accumulated in the soil at the upstream are transmitted to lower regions. The intensity of heavy metals transmission is high due to the existence of several mines in the catchment area. As a result, several types of cancer have been reported among local people. By considering flood zone map approximately all orchards near villages are impressed by flood. Accordingly, there is one tree in each $2 \mathrm{~m}^{2}$ therefore flood zone map shows about $12 \mathrm{~km}^{2}$ of the area can be impressed by flood and more than 6000 trees can be damaged and destroyed during flood occurrence (Figure 9). According to the findings of Iran environmental protection agency, in the catchment area 188 kinds of vascular plants have been identified, which belong to the 40 plant families. Majority of plants are resistant to drought and salinity but weak to the shortage of food. Natural and vegetation landscape of the area mainly includes Qhlych species, Artemisia plants and strained spinach. Natural grown trees, which are distributed along river are impressed by flood and situated at the flood zone. There is no any data and information about their magnitude.

\section{Flood environmental effects on surface water quality}

Changes of river regime and water volume have direct effects on dam reservoir, especially when flood occurs. Mentioned effects may be environmentally positive or negative. Quantitative changes mentioned above are also 

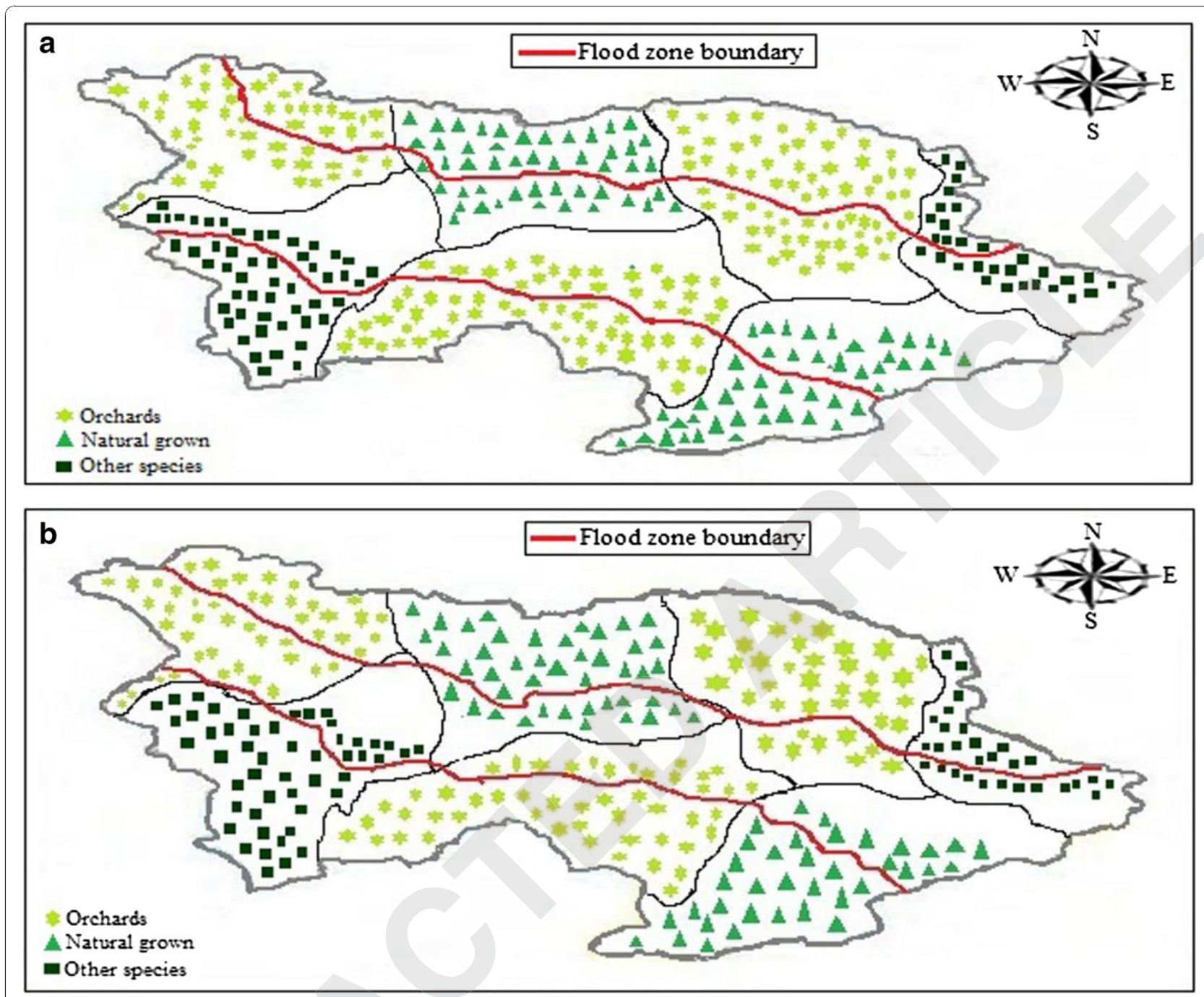

Figure 9 Flood environmental effects on plants in the study area based on flood zone map without dam (a), and with dam (b).

accompanied with hydro-physical and hydro-chemical changes. Changes in river ecosystem relatively because of quantitative and qualitative water changes affect life conditions of aquatic organism's habitants and other animals that live near the river. Decreasing of sediments at the estuary of the river results in decrease of river selftreatment power. Furthermore, water temperature at the next stages has effects on downstream ecosystem and physical and chemical qualities of waste watered land and aquatic organisms near the river. In Kerman province at villages and rural areas, which do not have plumbing system, people use traditional system of water supply is known as "Ghanat". In this system groundwater is used directly without treatment and purifications. After flood event, water quality changes because some factors such as sediments, nature of soil and mineral materials are noticeable. Based on our achievements, flooding increases some materials such as sulfate and metal concentrations in infiltrated water indicating some accumulation of stored oxidation products occur in the area of the mines, which are subjected to flooding. Some materials such as copper, aluminum and manganese concentrations are correlated. Based on the analysis of past recorded data of flood event in 1992, which obtained from Iran environmental protection agency the flood environmental effects on the surface water are noticeable. It was observed that the surface water temperature, DO, conductivity, turbidity, $\mathrm{pH}, \mathrm{BOD}, \mathrm{COD}$, TDS, TSS, $\mathrm{Cu}$ and Fe increase while salinity, planktons and nektons reduce with increase in the flood intensity (Table 6). The results of our analysis for the surface water quality were in a good agreement with similar studies performed to determine the changes of water quality during flood event [40]. Regarding to flood zone map in our case study generally all villages can impressed and those which are near flood zone can be affected more seriously. The regions located 
Table 6 Flood environmental effects on surface water quality for villages in and out of the flood zone

\begin{tabular}{llllll}
\hline Parameter & Unit & Value in flood zone & Value out of flood zone & Effect & Ratio of changes (in zone/out of zone) \\
\hline Temperature & ${ }^{\circ} \mathrm{C}$ & 27 & 24 & Increases & 1.13 \\
Salinity & $\mathrm{PSU}$ & 35 & 40 & Reduces & -0.88 \\
DO & $\mathrm{mg} / \mathrm{L}$ & 3.2 & 2.4 & Increases & 1.33 \\
Conductivity & $\mathrm{US}$ & 9000 & 6000 & Increases & 1.50 \\
Turbidity & $\mathrm{NTU}$ & 210 & 125 & Increases & 1.68 \\
$\mathrm{pH}$ & - & 9.3 & 8.4 & Increases & 1.11 \\
$\mathrm{BOD}$ & $\mathrm{mg} / \mathrm{L}$ & 130 & 95 & Increases & 1.37 \\
TSS & $\mathrm{mg} / \mathrm{L}$ & 1500 & 300 & Increases & 5 \\
TDS & $\mathrm{mg} / \mathrm{L}$ & 3500 & 900 & Increases & 3.88 \\
COD & $\mathrm{mg} / \mathrm{L}$ & 180 & 140 & Increases & 1.29 \\
Cu & $\mathrm{mg} / \mathrm{L}$ & 9 & 4 & Increases & 2.25 \\
Fe & $\mathrm{mg} / \mathrm{L}$ & 14 & 8 & Increases & 1.75 \\
Nektons & - & - & - & Reduces & - \\
Planktons (size) & $\mathrm{mm}$ & $(2-20)$ & $(20-40)$ & Reduces & - \\
\hline
\end{tabular}

in the flood zone map and out of flood zone map were analyzed separately. The results indicated that the flood environmental effect on the villages in the flood zone map is more significant than out of flood zone map. Therefore, the intensity of environmental effect of all considered contaminants for villages in flood zone/out of flood zone was greater than 1. As a result, the ratio of two important heavy metals, namely $\mathrm{Cu}$ and Fe in (flood zone) per (out of flood zone) were 2.25 and 1.75 , respectively. The concentrations of measured $\mathrm{Cu}$ and Fe in flood zone were 9 and $14 \mathrm{mg} / \mathrm{L}$ while the environmental standard limits in Iran for surface water are is 1 and $3 \mathrm{mg} / \mathrm{L}$, respectively.

After flood occurrence, during water flow along the river various minerals dissolve in water. Most of the minerals dissolving naturally in water along river flow are carbonate minerals, which dissolve in the form of bicarbonate. Corrosion is a chemical physical reaction between a substance and its surrounding, which leads to change in the substance characteristics. Formation of byproducts by corrosive waters, taste, odor and color problems in water as well as increase in turbidity are of the most important problems relate to corrosion. When the numerical value of RI is more than 6 there is a tendency to corrosion, in case the water is used in municipal water networks. Based on the results of LSI and RI for three selected stations in the flood zone, we concluded that the corrosion problems must be regarded and considered because of their importance and their environmental effects on the water quality (Table 7).

\section{Flood effects on fishes}

In another point of view Halilrood river is used as a water supplier for fishing. Flood occurrence has noticeable environmental effects on farms, which have located at the downstream of the study area and in our flood zone. The water characteristics such as TSS, DO, pH, temperature and heavy metals concentrations in the water after flood event can affect the fishes. The results of our study indicate that the effects of these characteristics are very crucial for the fishes due to high concentrations of these contaminants in the flood zone after flood event. Moreover, conditions of parasite growth such as Myxozoa can be prepared, which is the main parasite at this area after flood occurrence. According to an investigation, which conducted by Iran environmental protection agency in the Halilrood catchment area about 109 parasites has been examined, and about $73 \%$ of them were detected. Based on the analysis of data obtained from Iran environmental protection agency and regarding our flood zone where farms are located, seven different Myxobolus genera were detected such as Myxobolus samgoricus, M. cristatus, M. varicorhin, M. musajevi, M. karelicus, M. buckei and M. suturalis. While the first ordered 4 out of 7 parasites had been already reported from

Table 7 Water quality based on LSI and RI for selected stations in the study area

\begin{tabular}{llll}
\hline Station name & LSI & RI & Water quality based on LSI \\
\hline Hossinab & 0.2 & 7.27 & slightly scale forming and corrosive \\
Kahank & 0.52 & 6.37 & scale forming but non corrosive \\
Kenaruei & 0.41 & 6.83 & scale forming but non corrosive \\
\hline
\end{tabular}


different parts of Iran, M. karelicus, M. buckeiand M. suturalis are reported for the first time. During the present studies Capoeata damascina was introduced as a new host for M. musajevi, M. karelicus, M. buckei and M. suturalis. The study was conducted at four stations on the Halilrood, It was shown that the prevalence of infection in different stations are not alike. Effects of these parasites in the aspect of toll result from diseases are important and also have financial damages in fish farming. Figure 10 shows the magnified pictures of Myxobolus genera in the study area's fishes. In addition, after flood event, TSS concentration increases in the river. These solids settle and form a layer on spawn which has anaerobic condition and prevents dissolved oxygen to spawn and causes death of them.

\section{Flood and dam effects on archaeological sites}

Dam and flood have some effects on archaeological sites in the study area and on the other hand, they are endangered after flood occurrence indirectly. According to our flood zone map there are some archaeological sites, which we can refer to Eart's ancient city, Baft national park, Cheshme Aroos of Rabor, 5000 years old sycamore of Cheshme Aroos village, Kenar Sandal area at the adjacent to Halilrood River as most important historical monuments in the area. Along $400 \mathrm{~km}$ of the Halilrood River about 120 ancient area have been found which flood occurrence is one of the most threats to them. The Eart's ancient city, which is located under the ground and a part of it was destroyed simultaneously because of the intensity of flood at the area in 1992 and degree of soil erosion. Materials used in construction of historical monument are from brick, clay wall and stone, which are prone to erosion by explosion of the water. Beside these archaeological sites, which are situated near the river are endangered by land sliding. Sediment transmission and other damages are indirect effects of flood occurrence.

\section{Effects on flood vicinity and environmental health}

Environmental public health is concerned with aspects of the natural and built environment that may affect human health. Major floods pose great risk for everyone in the flooding vicinity [41]. Particularly high flooding often claims the lives of drowning victims. If people and animals residing in the flooded area cannot get to food, medications or treatments to survive, more lives can be lost. The physical damage done to buildings and cars often claims the lives of people and animals may be trapped during the disaster. The injured may not get to hospitals. The lack of clean drinking water to flood victims can cause illness. When water remains in a place like a pond or a pool for a long time and is immovable, viruses result from statgnated water such as shistozomaise increase their activities and have destructive effects on the people, other organisms and somewhat on the environment of the area. By considering the weather of the area and according to flood zone map many of these ponds are formed after flood occurrence, therefore they cover about $15 \mathrm{~km}^{2}$ of the study area and their effects would be noticeable on the area environmentally. The analysis of data obtained from Iran environmental agency and local organization in Kerman province combined with the results of flood zone map in our study area showed that the flood environmental health effects

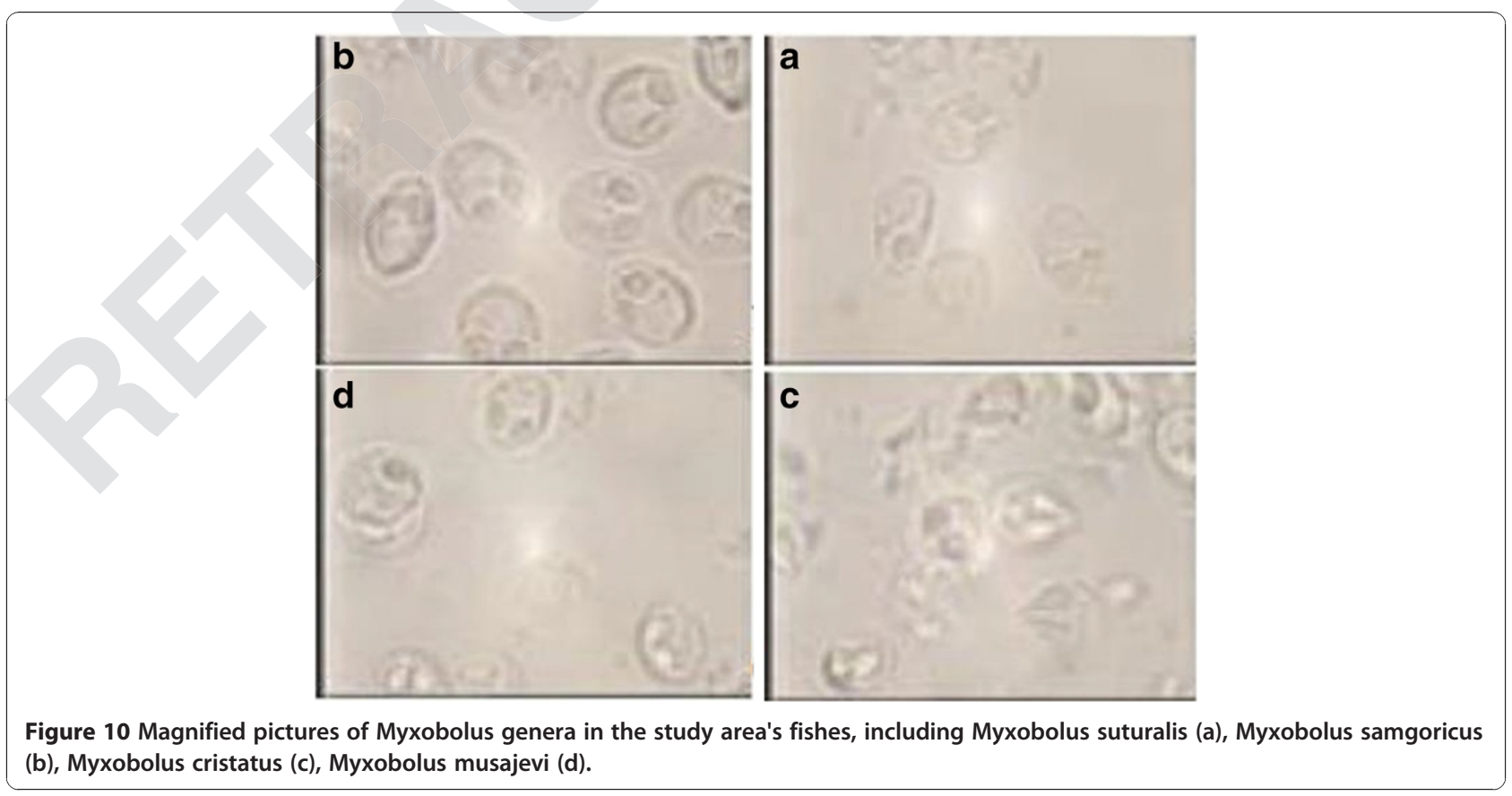


should be considered carefully. Based on our flood zone map, analysis of past recorded data for the study area and the formation of statgnated water and activities of viruses such as shistozomaise as well as bad quality of drinking water more than 100 people die because of these environmental health problems when flood occurs.

\section{Flood effects on soil characteristics}

The top soil of the earth crust is the most vulnerable component, which can be affected by flood. The washed away soil flows into adjacent water-bodies such as lakes and rivers and later gets swept away into the sea. Under constant wet conditions, when flood waters remain stagnant for days on a particular land area, there are grave implications on the soil chemistry. As the layer of water cuts off the supply of air to the earth, the fundamental chemistry of the soil is totally disturbed [42]. There are various mineral resources and regions with different soil characteristics in Kerman province. When flood occurs sediments and soil at different regions are transmitted to downstream land and also some of ions and mineral materials that are dissolved in water remain after water evaporation. The remaining soil has new characteristics and regarding our flood zone map for the study area the volume of changes is significant. Based on our measured data in the Halilrood catchment area, the soil texture is classified to five groups, including (1) clay loam (CL), (2) sandy loam (SL), (3) silty clay loam ( $\mathrm{SiCL}),(4)$ sandy clay loam (SCL), (5) and a region with no texture (Figure 11). As well as these from hydrological point of view, in the Halilrood catchment area soil classified to three groups, including (1) class B, which has medium effect on run off production and is consist of gravelly loam and sandy loam, (2) class $\mathrm{C}$, which has relatively large effect on run
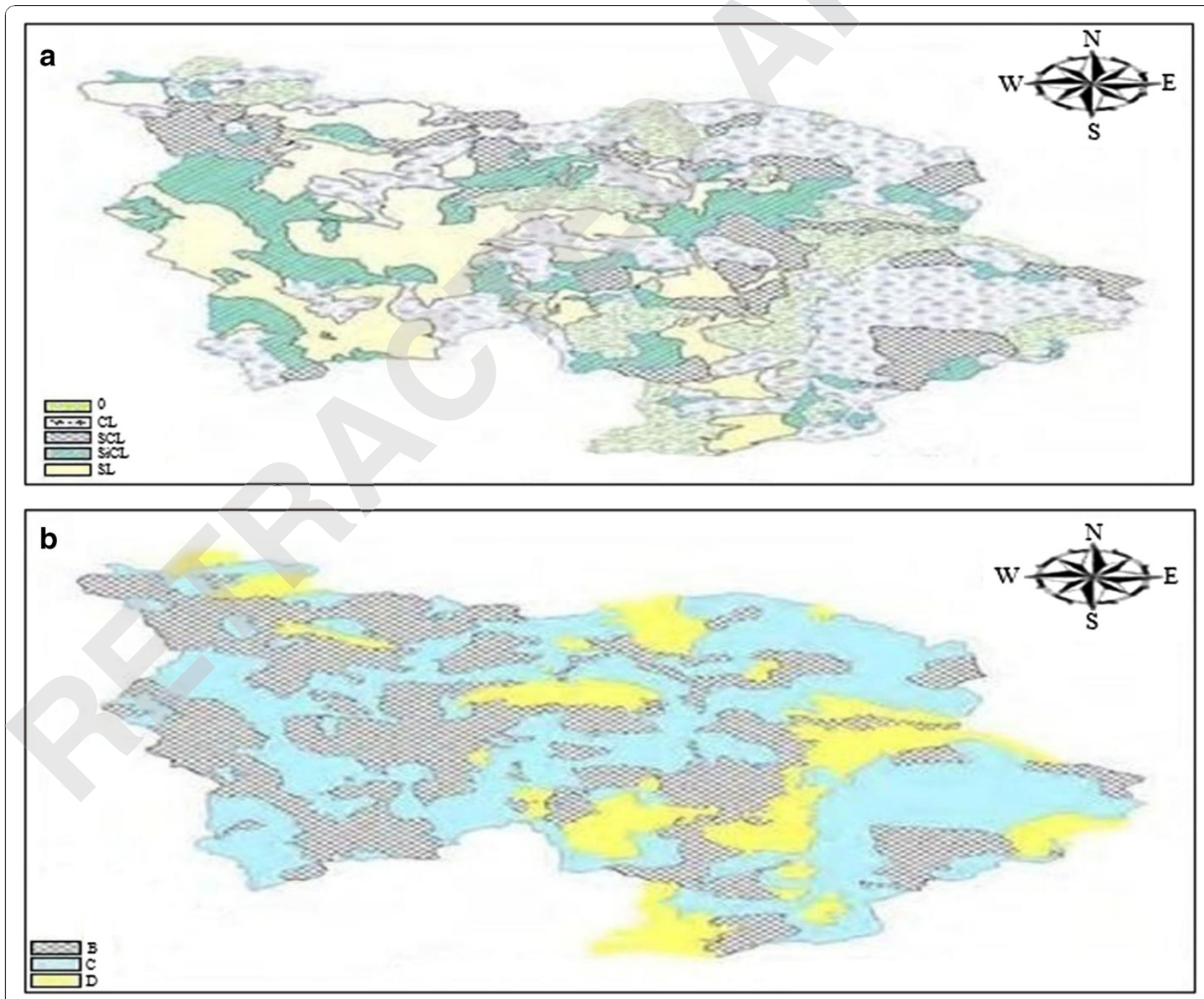

Figure 11 Soil texture classes of Halilrood catchment area (a), hydrologic soil groups of Halilrood catchment area (b). 
off production and is consist of loam and clay loam, (3) and class $\mathrm{D}$, which has very large effect on run off production and is consist of clay and silty soils (Figure 11).

Results of the soil texture and hydrologic soil groups for our flood zone combined with the past recorded data from Iran environmental protection agency showed that the mean of the sediments from the upstream to downstream was increased, which indicates existence of a bed gravel and sand at the upstream, and a silt bed at the downstream of the river. Rate of the negative curvature of some river sediments in the study area was caused by the existence of a great amount of large particles, because with effect of river flooding the small particles was washed. Regarding to the samples, which were tested according to the U.S. conservation service standards, the results showed that about \%64 of the sediments of the case study area, varied with skew from bad to very bad and their resistances to erosion were very low. Based on our achievements, the existence of Jiroft dam has some effects on the characteristics of soil in the study area when flood occurs. The results of the proportions of soil textures and hydrological groups of soil by considering flood zone map with and without dam for the Halilrood catchment area have been presented in Table 8. The results indicated that the existence of Jiroft dam decreases the transmission of clay and silty soils to the downstream of the area.

\section{Conclusions}

The environmental effects of flooding can be pretty wide-ranging, from the dispersion of low-level household wastes to the fluvial system to contamination of community water supplies and wildlife habitats with extremely toxic substances. On the other hand, flood preparedness activities, such as forecasting and warning systems, can help avoid some of these impacts. Therefore, environmental evaluation of the flood hazard sets the stage for the strategic assessment of redeveloping flood prone areas. Specifically, recurring losses and negative intrusions into environmental systems could be

Table 8 Proportions of soil textures and hydrological groups of soil with and without Jiroft dam

\begin{tabular}{lll}
\hline Soil group & With dam (\%) & Without dam (\%) \\
\hline Clay loam (CL) & 0.22 & 0.24 \\
Sandy loam (SL) & 0.27 & 0.23 \\
Silty clay loam (SiCL) & 0.20 & 0.21 \\
Sandy clay loam (SCL) & 0.23 & 0.22 \\
No texture (0) & 0.08 & 0.10 \\
Class B & 0.47 & 0.43 \\
Class C & 0.39 & 0.41 \\
Class D & 0.14 & 0.16 \\
\hline
\end{tabular}

avoided, or at least minimized, by identifying, measuring, and interpreting the magnitude and significance of environmental impacts associated with flooding. Flood zone mapping can be used as a new technique to assess environmental damages caused by flood occurrence in the region. In our case study by using flood zone mapping technique many advantages have been achieved by determination of flood effects, degree and intensity of probable damages. Furthermore, it has much efficiency in floodplain area management and flood controlling to reduce flood environmental damages.

The results of flood zone mapping indicated that the existence of Jiroft dam in study area can decrease flood zone from 260 hectares to 225 hectares and also it decreases $20 \%$ of flood peak intensity, therefore $14 \%$ of flood zone can be saved environmentally. It was observed that the agricultural lands around the river banks endangered by flood flow. Based on our calculations of flood zone map more than 60 percent of land goes under water can produce agricultural wastewater, which is a noticeable environmentally. Sinking of land affects the lives of some animals near the Halilrood catchment area and threatens their habitats when flood occurs. The most endangered mammals are foxes, jackals, hyenas, wild cats and caracals. Decrease of plants on the ground results in the probable negative environmental changes at the study area. Considering flood zone map approximately all orchards, which are near villages around the river are impressed by flood. Accordingly, there is one tree in each $2 \mathrm{~m}^{2}$ therefore flood zone map shows about $12 \mathrm{~km}^{2}$ of the area can be impressed by flood and more than 6000 trees can be damaged and destroyed during flood occurrence. The results indicated that the flood environmental effect on the villages in the flood zone map is more significant than out of flood zone map. Therefore, the intensity of environmental effects of all considered contaminants for villages in flood zone per out of flood zone were greater than 1 . Based on the results of LSI and RI for three selected stations in the flood zone, we concluded that the corrosion problems must be regarded and considered because of their importance and their environmental effects on the water quality

The results of our study indicated that the effects of water characteristics such as TSS, DO, $\mathrm{pH}$, temperature and heavy metals are very crucial for the fishes due to high concentrations of these contaminants in the flood zone after flood event. Flood zone mapping showed that at the study area due to formation of statgnated water and activities of viruses such as shistozomaise as well as bad quality of drinking water more than 100 people die because of these environmental health problems when flood occurs. Based on our achievements, the villages around the river banks are threatened by flood seriously. 
Geological studies indicated that the natural characteristics of the region is in such a way that it can increase run-off volume. We concluded that some remedial works should be conducted by growing the environment like plant trees or vegetables in the region to reduce flood volume.

\section{Nomenclature}

HEC-HMS: hydrologic engineering center-hydrologic modeling system

HEC-RAS: hydrologic engineering center-river analysis system

GIS: geographic information system

NEXRAD: next generation radar

DEM: digital elevation model

IfSAR: interferometric synthetic aperture radar

H.R.: horizontal resolution

V.A.: vertical accuracy

RMSE: root mean squared error

NED: national elevation data

SRTM: shuttle radar topography mission

LiDAR: light ranging and detection

SCS: conservation service

$\mathrm{CN}$ : curve number

WMS: watershed modeling system

LSI: Langelier saturation index

RI: Risener index

DO: dissolved oxygen

BOD: biochemical oxygen demand

COD: chemical oxygen demand

TSS: total suspended solids

TDS: total dissolved solids

\section{$\mathrm{Cu}$ : Copper}

Fe: Iron

PSU: practical salinity unit

uS: units of micro Siemens

CL: clay loam

SL: sandy loam

SiCL: silty clay loam

SCL: sandy clay loam

\section{Acknowledgements}

We wish to thank Mohammad Reza Ghanbari and all people who helped us with the field work. The financial support for this work was provided by the authors.

\section{Author details}

${ }^{1}$ Department of Civil Engineering, K.N. Toosi University of Technology, Vanak Square, Tehran, Iran. ${ }^{2}$ Department and Faculty of Basic Sciences, PUK University, Kermanshah, Iran.

Received: 29 December 2013 Accepted: 14 December 2014 Published: 27 December 2014

\section{References}

1. Sun D-P, Xue H, Wang P-T, Lu R-L, Liao X-L: 2-D numerical simulation of flooding effects caused by South-to-North water transfer project. J Hydrodyn Ser B 2008, 20(5):662-667.
2. Amini A, Ali TM, Ghazali AHB, Aziz AA, Akib SM: Impacts of land-use change on streamflows in the Damansara Watershed, Malaysia. Arab J SCi Eng 2011, 36(5):713-720.

3. Hinderer M: From gullies to mountain belts: a review of sediment budgets at various scales. Sediment Geol 2012, 280:21-59.

4. Dikbas F, Firat M, Koc AC, Gungor M: Defining homogeneous regions for streamflow processes in Turkey using a K-means clustering method. Arab J Sci Eng 2013, 38(6):1313-1319.

5. Alexandrov $Y$, Laronne JB, Reid I: Suspended sediment concentration and its variation with water discharge in a dryland ephemeral channel, northern Negev, Israel. J Arid Environ 2003, 53(1):73-84.

6. Dunkerley D, Brown K: Flow behaviour, suspended sediment transport and transmission losses in a small (sub-bank-full) flow event in an Australian desert stream. Hydrol Process 1999, 13(11):1577-1588.

7. Boardman J, Evans R, Ford J: Muddy floods on the South Downs, southern England: problem and responses. Environ Sci Policy 2003, 6(1):69-83.

8. Svendsen J, Stollhofen H, Krapf CB, Stanistreet IG: Mass and hyperconcentrated flow deposits record dune damming and catastrophic breakthrough of ephemeral rivers, Skeleton Coast Erg, Namibia. Sediment Geol 2003, 160(1):7-31.

9. Auynirundronkool K, Chen N, Peng C, Yang C, Gong J, Silapathong C: Flood detection and mapping of the Thailand Central plain using RADARSAT and MODIS under a sensor web environment. Int J Appl Earth Obs Geoinf 2012, 14(1):245-255

10. Xia C, Pahl-Wostl C: Understanding the development of flood management in the middle Yangtze River. Environ Innov Soc Transit 2012, 5:60-75.

11. Feldman, AD: Hydrologic Modeling System HEC-HMS: Technical Reference Manual. US Army Corps of Engineers, Hydrologic Engineering Center, (2000).

12. Halwatura D, Najim M: Application of the HEC-HMS model for runoff simulation in a tropical catchment. Environ Model Softw 2013, 46:155-162.

13. Bajwa, H, Tim, U: Toward immersive virtual environments for GIS-based Floodplain modeling and Visualization. In: Proceedings of 22nd ESRI User Conference 2002.

14. Horritt $M$, Bates P: Evaluation of $1 D$ and $2 D$ numerical models for predicting river flood inundation. J Hydrol 2002, 268(1):87-99.

15. Fan $\mathrm{C}, \mathrm{Ko} \mathrm{C}-\mathrm{H}$, Wang W-S: An innovative modeling approach using Qual2K and HEC-RAS integration to assess the impact of tidal effect on River Water quality simulation. J Environ Manag 2009, 90(5):1824-1832.

16. Knebl M, Yang Z-L, Hutchison K, Maidment D: Regional scale flood modeling using NEXRAD rainfall, GIS, and HEC-HMS/RAS: a case study for the San Antonio River Basin Summer 2002 storm event. J Environ Manag 2005, 75(4):325-336.

17. Anderson M, Chen Z-Q, Kavvas M, Feldman A: Coupling HEC-HMS with atmospheric models for prediction of watershed runoff. $J$ Hydrol Eng 2002, 7(4):312-318.

18. Hadadin N, Tarawneh Z, Shatanawi K, Banihani Q, Hamdi MR: Hydrological analysis for floodplain hazard of Jeddah's drainage Basin, Saudi Arabia. Arab J Sci Eng 2013, 38(12):3275-3287.

19. Siddiqui QTM, Hashmi HN, Ghumman AR: Flood inundation modeling for a watershed in the pothowar region of Pakistan. Arab J Sci Eng 2011, 36(7):1203-1220.

20. Liu X, Zhao X: The research on flood character grid base on GIS. Energy Procedia 2012, 16:1225-1229.

21. Smith PN: Hydrologic data development system. Trans Res Record: J Trans Res Board 1997, 1599(1):118-127.

22. Naeem UA, Nisar H, Ejaz N: Development of empirical equations for the peak flood of the Chenab river using GIS. Arab J Sci Eng 2012, 37(4):945-954.

23. Marston RA, Mills JD, Wrazien DR, Bassett B, Splinter DK: Effects of Jackson Lake Dam on the Snake River and its floodplain, Grand Teton National Park, Wyoming, USA. Geomorphol 2005, 71(1):79-98.

24. Lianqing $X$, Zhenchun $H$, Xiaoqun $L$, Yongkun $L$ : Numerical simulation and optimal system scheduling on flood diversion and storage in Dongting Basin, China. Procedia Environ Sci 2012, 12:1089-1096.

25. Charrier R, Li Y: Assessing resolution and source effects of digital elevation models on automated floodplain delineation: a case study from the Camp Creek Watershed, Missouri. App/ Geogr 2012, 34:38-46.

26. Vazquez R, Feyen J: Assessment of the effects of DEM gridding on the predictions of basin runoff using MIKE SHE and a modelling resolution of $600 \mathrm{~m}$. J Hydrol 2007, 334(1):73-87.

27. Sanders BF: Evaluation of on-line DEMs for flood inundation modeling Adv Water Res 2007, 30(8):1831-1843. 
28. Khazaei, MR, Zahabiyoun, B, Saghafian, B, Ahmadi, S: Development of an Automatic Calibration Tool Using Genetic Algorithm for the ARNO Conceptual Rainfall-Runoff Model Arab J Sci Eng 1-15 (2013).

29. Scanlon BR, Healy RW, Cook PG: Choosing appropriate techniques for quantifying groundwater recharge. Hydrogeol J 2002, 10(1):18-39.

30. Aronica GT, Candela A, Fabio P, Santoro M: Estimation of flood inundation probabilities using global hazard indexes based on hydrodynamic variables. Phys Chem Earth Parts A/B/C 2012, 42:119-129.

31. Metcalf I: Wastewater engineering; treatment and reuse. McGraw-Hill, (2003)

32. Andrew, D: Standard methods for the examination of water and wastewater none, (2005).

33. Elmolla ES, Chaudhuri M: Combined photo-Fenton-SBR process for antibiotic wastewater treatment. J Hazard Mater 2011, 192(3):1418-1426.

34. Haque CE, Kolba M, Morton P, Quinn NP: Public involvement in the Red River Basin management decisions and preparedness for the next flood. Glob Environ Chang Part B: Environ Hazard 2002, 4(4):87-104.

35. Lind $\mathrm{N}$, Hartford $\mathrm{D}$, Assaf $\mathrm{H}$ : Hydrodynamic models of human stability in a flood 1. JAWRA J Am Water Resour Assoc 2004, 40(1):89-96.

36. Erdlenbruch K, Thoyer S, Grelot F, Kast R, Enjolras G: Risk-sharing policies in the context of the French Flood Prevention Action Programmes. J Environ Manag 2009, 91(2):363-369.

37. Mauclaire L, Gibert J: Effects of pumping and floods on groundwater quality: a case study of the Grand Gravier well field (Rhône, France). Hydrobiol 1998, 389(1-3):141-151.

38. Claret C, Fontvieille D: Characteristics of biofilm assemblages in two contrasted hydrodynamic and trophic contexts. Microb Ecol 1997, 34(1):49-57.

39. Baky A, Zaman A, Khan A: Managing flood flows for crop production risk management with hydraulic and gis modeling: case study of agricultural areas in Shariatpur. APCBEE Procedia 2012, 1:318-324.

40. Howitt JA, Baldwin DS, Rees GN, Williams JL: Modelling blackwater: predicting water quality during flooding of lowland river forests. Ecol Model 2007, 203(3):229-242.

41. Tariq MAUR, van de Giesen N: Floods and flood management in Pakistan. Phys Chem Earth Parts A/B/C 2012, 47:11-20.

42. De-Campos AB, Mamedov Al, Huang C-H: Short-Term reducing conditions decrease soil aggregation. Soil Sci Soc Am J 2009, 73(2):550-559.

\section{Submit your next manuscript to BioMed Central and take full advantage of:}

- Convenient online submission

- Thorough peer review

- No space constraints or color figure charges

- Immediate publication on acceptance

- Inclusion in PubMed, CAS, Scopus and Google Scholar

- Research which is freely available for redistribution 